\title{
Synchronous personal method of language studying speech behavior in implicit pragmalinguistics
}

\author{
Irina A. Zyubina - Marianna Iu. Filippova - Natalia A. Minakova - Liudmila \\ V. Krivoshlykova - Irina G. Anikejeva
}

DOI: 10.18355/XL.2020.13.04.06

\begin{abstract}
Any speech behavior reflects personal characteristics of the speakers. In speech, communicants actualize their individual, social, national, and cultural characteristics, which are in an inseparable unity and represent a specific linguistic behavior. However, the authors note that the features of the actualization of these characteristics and their combination change, which depends on the communication situation and on a particular speech genre. The main approach of the research is the synchronouspersonal approach. The authors examined and analyzed examples of the speech behavior of a particular prosecutor. They studied his speeches in a jury, in a professional court, and a newspaper article written by him. All speeches have similar features: 1) the same parameters of the personal, social and objective planes of the implicit speech strategy "Participation / Nonparticipation of members of communication in a speech event", 2) almost similar indicators of certain / uncertain statements of the implicit speech strategy "Sure/Unsure speech behavior of an author" in the speech to professionals in the court and in the newspaper text. All three speeches have more negative attitudes to the speech event. The study distinguished significant differences. The indexes of all the planes in the speech before the jury differ in comparison with the speech before the professionals and in the newspaper article. The authors revealed a strict connection between the sender's speech behavior and various targets of the addressee. Speech behavior also depends on the recipients of these texts. It has been proved that human speech behavior is not a static system, and it can change, which depends on communicants' interaction.
\end{abstract}

Key words: pragmalinguistics, synchronous personal method of study, implicit pragmatic strategy, speech behavior, prosecutor

\section{Introduction}

A human being is the only one on the Earth that does not have such a genetic program of life, in which its activity will be strictly determined. But other representatives of the animal world (unlike a Homo Sapiens) always have a 'fixed action' model, including a complex number of actions (different rituals, such as courtship or coupling). Following Chuldini (2001) we consider, that "the fundamental feature characteristic for these models is a consistent repetition of reactions while being presented certain stimuli. Regarding a human being, scientists concluded that the genetic background determines about 50 percent of personal characteristics, and 50 percent of these characteristics are influenced by the external environment."

A man does not have an exact program of life, therefore the only way for a person to survive is to hope for the help of social reality. The people themselves create this reality contained in a special natural environment. Being involved in the constant process of socialization, receiving and processing information, people act according to certain patterns of behavior. Gradually, they are getting their own program of life, determined by its nature from the outside (see more: Chuldini, 2001).

On the one hand, it can cause something like a choice freedom and a huge space for a personal inventiveness and creative talent, while on the other it can cause freedom of actions and some mobility features of the activity program. Personal individuality and

XLinguae, Volume 13 Issue 4, October 2020, ISSN 1337-8384, ISSN 2453-711X 
ability for perception consider to be a mobile system. Nevertheless, an extra mobile human world threatens his being. That is why a person tries to do the best to save the stabilized behavior, to follow the algorithms and principles, which are accepted in a human society. It happens due to the repeating of definite stereotyped responses to a social important stimulus. Behavior stability is ruled by several social reflexes that are developed in the evolution process according to ready behavior models.

The main reason for stereotypes and simplification of thinking and human behavior is the inability to analyze every aspect of diverse social reality.

The purpose of the article is to describe the essence of the synchronous-personal method of learning the language of speech behavior from the position of the implicit pragmalinguistic aspect.

\section{Literature Review}

Sometimes the problems of life and death are very difficult to solve, a human being can have time, which is extremely limited or personal emotions can be very great. So, in this case people must react quickly, without any analysis of the coming information, in other words, to react at an unconscious level. The term is a 'stereotyped behavior'. The main feature of this level is in the fact that an ordinary person is not able to know and recognize definite features of structure, behavior frontiers and significant elements that a person always uses implicitly (Sepir, 1993, p. 598).

The implicit following of some definite stereotypes of behavior depends on the belonging of an addresser to a particular social group, to some significant terms and circumstances of communication (Karasik, 2000, p. 37-64).

These circumstances may include:

(a) communicative intentions of an author;

(b) relationships between an addresser and addressees;

(c) all sorts of "facts" that are meaningful and random;

(d) common ideological features and the stylistic climate of the era in general, and of environment and specific individuals to whom the information is directly or indirectly addressed, in particular; (e) genre and stylistic features of both the message and the communicative situation, in which it is included;

(f) the set of associations with the previous experience (Gasparov, 1996, p.10).

So, not all people are able to give an explanation why they behave in definite situations differently. It depends on the psyche of every person. Psyche being a brain function is a very important one, with the help of which human organism operates. Through the psyche all kinds of the external world effects influence the body. Especially it is important in the case of existing social reality. The influence of the outside world - individual social experience - creates complex dynamic system functional formations of the brain, that humans, from the social and psychological point of view, consider to be the concept of personality (Myasishchev, 1960, p. 10).

The public consciousness, which functions are at three main levels: existential, reflexive, and spiritual, forms and determines the individual culture of a member of society. It is the very existential level of consciousness that we can observe. It manifests itself in the communication of people and their behavior. According to recent research, a state that can be called unconscious governs from 92 to 98 percent of human behavior. Even in childhood, the existential level of consciousness is assimilated, being the basis that then becomes unconscious. As for reflective consciousness, the process of its formation lasts throughout all the life with the help of self-study, teaching someone, transferring knowledge, meditations on reality, on the behavior of others and one's own behavior. The spiritual level of consciousness is achieved in society by only a few persons (Prokhorov, Sternin, 2011).

All children copy the adults' behavior, which surrounds them since the very beginning of their lives. But it should be noticed that just copying cannot be a stereotype. 
Definite behavior facts become 'a stereotype of behavior' only if they are often repeated, and as a result of this numerous repeating they become automated.

Stereotyped speech behavior can be due to the constant social characteristics of a person: their social position, profession, age, sex, and marital status; and due to variable characteristics determined by the situation: the role of a buyer, a passenger, a client. Therefore, a person's belonging to a particular professional type requires them to have an idea of the typical stereotypes of professional conduct.

Personal perception is depended on profession belonging of all the communicants. If people are having the same professional activity for a long time, they begin acting according to strict stereotypes, and such a behavior is a so called 'professional habit.' More often such professional habits are met in the spheres, which relate to people (for example, in medicine, theatre, law enforcement) (Bodaliov, 1995, p. 168). Without any doubt, it is also true for a profession of a public prosecutor, that is why in Russian one can even hear a word-expression 'a prosecutor tone.'

Each person has characteristic reactions, which he or she expresses in individual behavior. Hence there are some options in human speech. In the process of transition of these variants of the reaction from random to permanent, when they have not yet become pathology, one can speak of the appearance of accentuations of personality qualities.

By the way, about half of the total population can be considered highly personalized (Leongard, 1989, p. 271). Accentuations of a character are extreme variants of a norm where certain traits of character are greatly predominant.

A character quality is a manifestation of a meaningful attitude towards facts and towards one's own actions. Integrity, honesty, cheerfulness, rigor, exactingness, sociability, sensitivity, and other character traits are clearly visible. They originate in relationships with reality, other people, and ourselves (Lichko, 1983, p. 22).

Paying attention to the phenomenon of 'an accentuated personality', one cannot fail to mention professional accentuations, which consist in the manifestation of typical features, that is very important for representatives of all professions. A professional accentuation is a combination of mental, psychological, and physiological personality traits. We can see it in the specifics of appearance, clothing, behavioral traits, along with the peculiarities of the human psyche and speech, existing in the form of drives or formed under the influence of the profession.

The nature of this activity, which is of a public character, often leads to a professional 'deformation' of prosecutors. Their psychological characteristics, as well as the way of communication play an important role.

The term 'deformation' means not only the designation of all kinds of changes in the shape of objects and phenomena of the external world, but also personality changes that occur due to a particular profession. Therefore, this also applies to the activities of public prosecutors.

Deformations of the individuality of a public prosecutor do not happen spontaneously, because of aging, but as a result of the activities they carry out. For example, it was found that professionally important characteristics of cognitive processes tend to be improved or stabilised, depending on the length of working, and the parameters that do not participate in professional activities deteriorate. At the same time, there is a reduction and stereotyping of ranges, of kinds of professional activities, of which the most effective behavioral reactions remain. Among personal features, the changes are reflected in the growth of self-esteem. According to received information, the degree of extra-high self-esteem is in direct proportion to the length of service, and at the same time there is also a rise of professional identity.

The legal profession of a public prosecutor promotes both positive qualities (high moral principles, endurance, calmness, discipline, open-mindedness, and the ability to communicate to people and to establish contact with them) and negative ones

XLinguae, Volume 13 Issue 4, October 2020, ISSN 1337-8384, ISSN 2453-711X 
(indifference to people, their lives, feelings and interests, excessive suspicion, rudeness, careerism, etc.).

Prosecutors, like representatives of other professions, suffer from professional deformations. But these professional deformations are one of the most dangerous ones, since prosecutors become overly suspicious, do not trust people, and suspect everyone. Even inaction for them symbolizes someone's evil intent. We can see the culprit in all suspects. Over the years, such an attitude towards life forms a strong pessimism and intolerance towards people among prosecutors. And from the point of view of Psychology, when a person evaluates another one, he assesses not only the qualities of the person assessed, but this assessment also testifies to the personality of the assessor, in our case, the personality of the judge. These assessments help to judge a person's experience, the level of their development as a representative of a particular group or team. This assessment shows the psychological maturity of the individual and some of their professional features. Therefore, the specificity of communication is that such an interaction serves to reveal the psychological qualities of people. This distinguishes communication from some other activities.

All things considered, one must say that speech behavior and personal characteristics of communicators represent an inseparable unity of individual, social and nationalcultural peculiarities of behavior. However, we believe that the specificity of expression and combination of these features varies depending on the specific situations of communication, including speech genres. It is reasonable to turn to the methods of studying speech behavior in different genres from the point of view of Implicit Pragmalinguistics (Levinson, 1983; Matveeva, 1993; Zheltukhina, Zyubina, 2018).

\section{Methodology}

From the point of view of Implicit Pragmalinguistics the following methods are distinguished: a synchronous-personal (different genres, one author, one period), diachronic-personal (one author, one genre, different age periods), synchronousinterpersonal (one speech genre, different authors, one period).

A synchronous-personal method is used in this study when there is an analyse of the speech behavior of Gennadiy Vladimirovich Trukhanov, that is one public prosecutor. And his speeches are studied in various speech genres: the text spoken before the jury, the speech in the professional trial (2000b) and the article from the newspaper Vecherniy Rostov [Evening Rostov] (2000a).

The kinds of speech behavior are called "implicit strategies of the addresser's speech influence on the addressee" (Matveeva, 1993, p. 96-262). Implicit strategies are divided into two types: emotional oriented and connotative oriented. It is easy to understand the connection between emotional oriented strategies and the emotive function of speech, which is focused on the addresser of the text. In this case there is an expression of the addresser's subjective attitude, which is psychological by its nature. The addressers show their attitude to the uttering. So, the emotive speech function can be associated with their attitude to what is said, with their feelings, in other words, with the subjective world of the addresser. This function reflects the speaker's self-esteem, and their need to be heard and understood (Kunitsina, Kazarinova, Pogolsha, 2002, p. 61). There are different kinds of emotion-oriented strategies:

- "Participation/Nonparticipation of members of communication in a speech event"

- "Sure/Unsure speech behavior of an author"

- "The author's probabilistic evaluation of a speech event as real / unreal."

Connotative-oriented strategies reflect speech behavior of a prosecutor directed at the receiver. The title of this strategy contains a reference to another function of speech connotative (regulatory or directive). The connotative function reflects certain needs of a person, for example, to achieve goals or to influence other people (Kunitsina, 
Kazarinova, Pogolsha, 2002, p. 61), and here follows a list of connotative-oriented strategies:

- "The sender's formation of addressee's attitude to a speech event by evaluation"

- "The author's accentuating of the elements of an utterance"

- "Satisfaction / Dissatisfaction of addressee's pragmatic expectations by an addresser".

Some pragmalinguists (Levinson, 1983; Matveeva, 1993; Voutilainen et al., 2014; Boeva-Omelechko et al., 2018; Kovtunenko et al., 2018; Zheltukhina et al., 2018; Zheltukhina\&Zyubina, 2018; Tameryan et al. 2019) developed the theory and methodology of the pragmalinguistic and psycholinguistic analysis in their researches. There is a study based on the results of the pragmalinguistic experiment, where the speech behavior of the public prosecutor is analysed. It is carried according to the emotional oriented strategies "Participation/nonparticipation of members of communication in a speech event" and "Sure/Unsure speech behavior of an author," and in accordance with the connotative oriented strategy "The sender's formation of addressee's attitude to a speech event by evaluation."

\section{Results and Discussion}

There is ananalysis of the public prosecutor's speech behavior with the help of a synchronous personal approach to the texts of various genres created in one period, by the author G.V. Trukhanov (2000a, 2000b), who is also a public prosecutor of the Regional Prosecutor's Office (Rostov-on-Don, Russia). In this concern there are some questions:

Does the prosecutor have different types of speech behavior in different speech genres? Is the speech behavior of this public prosecutor before a court professional, the jury and in the newspaper article on criminals the same? If it is so, why are there definite peculiarities in his speech behavior? What are they connected with?

The unit of analysis is a minor syntactic group (MSG in short). So, according to the stated implicit strategies 1,214 MSGs were studied in this paper.

\section{Participation/Nonparticipation of members of communication in a speech event"}

This strategy is actualised in one of the three following speech planes: the plane of personal participation, the plane of social participation, and the plane of objective participation (Matveeva, 1993, p. 98-101). Using the "personal plane," the author actualises the participation either of an addresser or an addressee in a speech event. "Social plane" shows us that both an addresser and an addressee act in communication. Finally, in the plane of objective participation the addressee's attention focuses on the objectivity of a speech event, regardless of participation/nonparticipation of the members of communication.

According to the results of the studied texts, the average speech-genre index of the plane of objective participation is the highest at 76.2 percent. It is interesting to note that the index of the plane of objective participation in the speech before a professional court (92.6 percent) is nearly equal to the same index of the newspaper article (92.5 percent). The plane of the objective participation is predominant if we compare it with other planes of this very implicit speech strategy. It can be caused by the fact that, first, the public prosecutor speaking before the court must charge the defendant on behalf of the state. It is necessary to base only on the exact factual circumstances of the committed crime. The public prosecutor must not evaluate the evidence publicly, or give any comments. The public prosecutor even does not have an appropriate procedural form for this very purpose.

From another point of view, the large plane of the objective participation, which is observed in the newspaper article is due that the general aim of the sender is

XLinguae, Volume 13 Issue 4, October 2020, ISSN 1337-8384, ISSN 2453-711X 
informing the readers about the situation in Rostov-on-Don Regional Court as impartially as it is possible. In both cases, the focus on the objective sides of reality arouses the readers' trust in the given facts.

The average speech genre plane of the personal participation is $16.2 \%$. The highest index of this plane (22.7 percent) can be seen in the speech of G.V. Trukhanov before the jurors. The author is unconsciously eager to be the leader, and influences the jurors with the power of his authority. But as for the text of the newspaper article, the public prosecutor unconsciously does not have an aim of having a personal influence on his readers. So, the plane of the personal participation goes just to $5.9 \%$. One can also see a rather low index of the personal participation in G.V. Trukhanov's speech in the court of professional judges - it is just $7.4 \%$. This fact relates to the situation when the state prosecutor gives a speech before heterogeneous audience but not different kinds of people as in a trial by the jury. But before the people of the same profession, of the same level of education, who are already specialists in the details of the case. The speeches to the professional judges are very formal, and are always prepared according to a well-known pattern. Here, the state prosecutor unconsciously tries to influence the professional trial not by the force of his authority, but by giving the information about the facts of the case.

About the actualisation of the plane of social participation, it can be correlated with the cooperative type of behavior. The division into "we" and "they" is more ancient than the division into "I" and "you." "We" is considered to be someone's own, to be close; whereas, "they" is considered to be somebody else's, to be strange. Internal doubts of a person, their hesitations while making every decision, is the process of experience and a choice of the answers to the following questions: Who is the closest? Who is a friend? Who is a stranger or even an enemy? To persuade, a public prosecutor must attract the positive attitude of their audience. That is why the highest level of the "social plane" (12 percent) is in Trukhanov's speech before the jury. The public prosecutor is trying to become as close to the jury as it is possible. From the point of view of Psychology, any jury representative is guided in their conclusions by their own reasons, mentality, self-conscience, sense of justice and duty, life experience, and responsibility (Chufarovskiy, 1995, p. 233). That is why creation a feeling of being in one community and the personal trust between a public prosecutor and a diverse group of jurors cannot be overestimated.

To a lesser degree, the plane of social participation is actualised by G.V. Trukhanov when speaking to the reader of the newspaper (1.6 percent). In addition, we do not see signs of this plane in the speech before the professional judges. In this case the speech sender does not look for the cooperation. The public prosecutor understands that his power and the judges are strictly differentiated. What is more, it often happens that the judge already has his own opinion and the prosecutor understands it. Therefore, the public prosecutor's speech is formal. So, professional trials differ from the ones by the jury, which demand the adversarial principle, requiring the public prosecutor to demonstrate high professionalism and personal responsibility.

\section{II. "Sure/Unsure speech behavior of an author"}

The strategy "Sure/Unsure speech behavior of an author" is actualised with the help of two speech planes: the first is a certain statement and the second one is an uncertain statement.

During court sessions, prosecutors have a complete autonomy in deciding, which line of conduct to choose and which decision to make (Alekseev, Yastrebov, 1998).

The main quality of all the prosecutors is the belief in their own righteousness. To influence an individual, especially if it is a group of people who differ in gender, age, manifestation of temperament, education, different levels of intelligence, etc., prosecutors should have certain personal socio-psychological characteristics. These 
qualities include the following manifestations: bright abilities of the organizer, a high level of initiative, striving to achieve goals, large experience, developed communication skills and external attractiveness, high awareness and, finally, awareness of a high level of authority and personal prestige (Porubov, 2004, p. 76).

In other words, prosecutors as representatives of the Law should be confident in court and speak accordingly. The results of the conducted research confirm this point of view. The average speech-genre index of the confident statement in G.V. Trukhanov's speech is quite high at $39.5 \%$.

But in the court speech before the jury, he actualized the highest level of certain statements $(48.8 \%)$. This is not surprising, since in this type of speech it is extremely important to convince the jury that you are right. Representatives of Legal Psychology argue that you can convince or persuade a listener only if an addressee is convinced that he is right. This makes the performances passionate and emotional. If speakers are confident in themselves, they make you believe them, share emotions and sincerity, and in this case, it is easier for the prosecutor to influence the mind of the addressees, to convince them of the correctness of their views and lead to the adoption of a different decision.

As for G.V. Trukhanov's speeches in front of the professional judges, here the prosecutor actualizes cautious speech behavior (77.4\%). In these examples, on a subconscious level, he is more uncategorized, and such speech behavior leads to a leveling of antagonism on the part of the professionals who are like him.

That is why in the implicit speech strategy "Sure/Unsure speech behavior of an author", the indicators of certain/uncertain speech also differ from each other depending on the addressees of the information, as, indeed, in the previous strategy.

\section{III. "The sender's formation of addressee's attitude to a speech event by evaluation"}

In any message there are two sides: rational and emotional. The rational essence runs through people's evidence, special facts, and the strength of logic. Emotions do their job with the help of listener perception, which can be caused at the very moment of sharing the definite message. And it is clear, that the way to human hearts lies not only through their minds but also through the emotional side (Porubov, 2004, p. 81).

Even in the nineteenth century it was known that the jury does not argue about what crime the defendant committed but about what kind of a person they are. That is, the emotional side of things and evaluation of the deeds play an important role in reaching a verdict.

There are three planes of the implicit speech strategy "The sender's formation of addressee's attitude to a speech event by evaluation": the plane of positive attitude, the plane of neutral attitude and the plane of negative attitude.

As it is known the main target of the prosecution speech is to form negative attitude to the committed crime, to show bad consequences with the help of the speech for the prosecution. Speaking about the average speech genre index of the plane of forming negative attitude towards a speech event one can see $38.6 \%$ in these speeches. The biggest index of the negative attitude is in G.V. Trukhanov's speech in the professional court, which is $49.1 \%$. Nevertheless, this public prosecutor has the lowest plane of positive attitude (it is just $3.5 \%$ ). Probably, it is because of widespread characteristic features of the courts without a jury to convict. It will be enough to say that in Russia 18 percent of verdicts are "not guilty" in trials by jury, and only 0.02 percent in an ordinary court, that is a professional one.

G.V. Trukhanov showed the lowest neutral plane of evaluation, that is $43.5 \%$, in the newspaper article "Vecherny Rostov", whereas the average speech-genre index is $52.7 \%$. It can relate to the fact that all newspaper texts, as a rule, affect and have high expressiveness. What is more, one can also observe the highest index of positive

XLinguae, Volume 13 Issue 4, October 2020, ISSN 1337-8384, ISSN 2453-711X 
evaluation, which is $11.5 \%$, and a rather high negative attitude to an event $-45 \%$. In the whole, the absolute emotional intensity of his speech behavior in this genre goes up to $56.5 \%$. In the article there is a burning desire of the author to be interesting, to attract his readers, so G.V. Trukhanov used to actualizing both positive and negative types of the event evaluation, even if he does it unconsciously.

According to the strategy, we can conclude that the author draws attention of the addressees to a positive, neutral, or negative assessment, which depends on his desire to form a certain attitude of the addressees to the given information.

So, we can see, an individual speech behavior is not considered to be an invariable system and it can change due to an interaction situation, but it can save its specificity. Having analyzed the public prosecutor speech from the synchronous personal point of view in the aspect of Implicit Pragmalinguistics, now it is possible answer the posed questions.

\section{Conclusion}

G.V. Trukhanov's speech behavior as a public prosecutor has definite peculiarities due to his addressee in various speech genres. There were studied different variants of his speech behavior: the text of the speech before the trial by jury, the speech in the professional trial and the newspaper article. All the texts have something in common. For example, there are almost the same planes of personal, social and objective attitude (according to the implicit speech strategy "Participation/nonparticipation of members of communication in a speech event"). Moreover, there are relatively similar indices of the planes of certain/uncertain statement (according to the implicit speech strategy "Sure/Unsure speech behavior of an author") in the speeches in the professional court and the newspaper article. Furthermore, in all three texts the negative attitude predominates. It must depend on the different author's aims, objectives and different addressees.

\section{Acknowledgments}

The publication has been prepared with the support of the RUDN University Program 5-100. The publication was carried out as a part of the program of supporting the publication activity of the Southern Federal University.

\section{Bibliographic references}

ALEKSEEV, A.I. - YASTREBOV, V.B. 1998. Profession: Prosecutor. Moscow: Yurist. ISBN 5-7975-0073-6.

BODALIOV, A.A. 1995. Personality and Communication. Moscow: Mezhdunarodnaya pedagogicheskaya akademiya. ISBN 5-87977-027-3.

BOEVA-OMELECHKO, N.B. - ZHELTUKHINA, M.R. - RYABKO, O.P. MATVEEVA, G.G. - MURUGOVA, E.V. - ZYUBINA, I.A. 2018. Unusual Antonyms: Inter-Part-Of-Speech Interaction in English Fictional Discourse. In: Space and Culture, India, vol. 6, n. 4, pp.112-121. eISSN 2052-8396.

GASPAROV, B.M. 1996. Language, memory, image. Linguistics of linguistic existence. Moscow: Novoe literaturnoe obozreniye. ISSN-0869-6363 ISBN 5-86793020-3.

CHUFAROVSKIY, YU.V. 1995. Legal psychology. Moscow: Pravoizakon. ISBN 5 $7858-0019-5$.

CHULDINI, R.B. 2001. Influence: Science and practice (4th ed.). Boston: Allyn \& Bacon. ISBN 978-0-205-60999-4

KARASIK, V.I. 2000. Ethnocultural types of institutional discourse. In: Ethnocultural specificity of speech activity. Moscow: Institut nauchnoy informatsii po obchshestvennym naukam RAN. ISBN: 5-248-01338-0.

KOVTUNENKO, I.V. - BYLKOVA, S.V. - BORISENKO, V.A. - MINAKOVA, N.A. - ROGACHEVA, V.I. 2018. Interview as a genre of new media communication: 
rhetorical relations and pragmatic effects. In: XLinguae, vol. 11, n. 2, pp. 95105. eISSN 2453-711X Available online: http://www.xlinguae.eu/2018_11_02_08.html

KUNITSINA, V.N. - KAZARINOVA N.V. - POGOLSHA V.M. 2002.Interpersonal communication. St. Petersburg: Piter-Yug. ISBN: 5-8046-0173-3.

LEONGARD, K. 1989. Accentuated Persons. Kiev: Vichsha shkola. ISBN: 5-11001299-7.

LEVINSON, S.C. 1983. Pragmatics. Cambridge: Cambridge University Press. ISBN 978-0521294140.

LICHKO, A.E. 1983. Psychopathy and character accentuation in adolescents. Leningrad: Meditsina. BBK: 88.48.

MATVEEVA, G.G. 1993. Hidden grammatical meanings and identification of the social person ("portrait") of the speaker: abstract of PhD. Rostov-on-Don. St. Petersburg.

MYASISHCHEV, V.N. 1960. Personality and neurosis. Leningrad: Izdatelstvo Leningradskogo universiteta. ISBN: 978-5-458-24994-2.

PORUBOV, N.I. 2004.Rhetoric. Minsk: Vshk. Shk. ISBN: 985-06-0918-4.

PROKHOROV, YU.E. - STERNIN, I.A. 2011. Russians: communicative behavior. Moscow: Flinta: Science. ISBN 978-5-89349-812-7 (Flinta), 978-5-02-033390-1 (Science). Available online: https://znanium.com/catalog/product/409919

SEPIR E. 1993. Selected works on Linguistics and Cultural studies. Moscow: Progress.ISBN: 5-01-002079-3.

TRUKHANOV G.V. 2000a.Criminals' Dreams. In: Vecherniy Rostov [Evening Rostov], 04.03.2000 (Newspaper articles from private archive of Trukhanov G.V.)

TRUKHANOV G.V. 2000b.Speeches for the prosecution. Records of judicial proceedings Rostov-on-Don: Regional Court.

VOUTILAINEN, L. - HENTTONEN, P. - KAHRI, M. - KIVIOJA, M. - RAVAJA, N. - SAMS, S. - PERÄKYLÄ, A. 2014. Affective Stance, Ambivalence, and Psychophysiological Responses during Conversational Storytelling. In: Journal of Pragmatics, vol. 68, pp. 1-24. ISSN: 0378-2166.

ZHELTUKHINA, M.R. - BUSYGINA, M.V. - MERKULOVA, M.G. - ZYUBINA, I.A. - BUZINOVA, L.M. 2018. Linguopragmatic aspect of modern communication: main political media speech strategies and tactics in the USA and the UK. In: XLinguae, vol. 11, pp. 639-654. ISSN 1337-8384.

ZHELTUKHINA, M.R. - ZYUBINA, I.A. 2018. Individual Speech Behavior of Russian-Speaking Prosecutors in the 19-20th Centuries: A Case Study in Implicit Pragmatics. In Lege artis. Language Yesterday, Today, Tomorrow. In: The Journal of University of SS Cyril and Methodius in Trnava. Warsaw: De Gruyter Poland, vol. 3, n. 2, pp. 251-306. ISSN 2453-8035.

TAMERYAN, T.Yu. - POPOVA, T.G. - REDKOZUBOVA, E.A. - ANIKEJEVA, I.G. - SEDLIAROVA, O.M. - SOLOVYEVA, N.S. 2019. Feminine perspective of ethnic business communication. In: Espacios, vol. 40, n. 34, 18 p. ISSN: 0798-1015.

Words: 5243

Characters: 34731 (19,30 standard pages)

Ass. prof. Irina Anatolevna Zyubina, $\mathrm{PhD}$

Institute of Philology, Journalism and Cross-Cultural Communication

Southern Federal University

105/42 Bolshaya Sadovaya Street

344006 Rostov-on-Don

Russia

irinazyubina@gmail.com

XLinguae, Volume 13 Issue 4, October 2020, ISSN 1337-8384, ISSN 2453-711X 
Ass. prof. Marianna Iurevna Filippova, $\mathrm{PhD}$

Law Institute

Russian University of Transport

9b9 Obrazcova Street

127994 Moscow

Russia

fm404@yandex.ru

Ass. prof. Natalia Alexandrovna Minakova, $\mathrm{PhD}$

Faculty of Philology

Peoples' Friendship University of Russia (RUDN University)

10/2 Mikluho-Maclay

117198 Moscow

Russia

naminakova@yandex.ru

Ass. prof. Liudmila Vladimirovna Krivoshlykova, $\mathrm{PhD}$

Faculty of Philology

Peoples' Friendship University of Russia (RUDN University)

10/2 Mikluho-Maclay

117198 Moscow

Russia

lvk1404@mail.ru

Ass. prof. Irina Goderzovna Anikejeva, $\mathrm{PhD}$

Department of Linguistics and Theory of Translation

Moscow Aviation Institute

125993, 4 Volokolamskoe highway,

Moscow,

Russia

Irganik3@mail.ru 